\title{
EFFECTIVENESS OF ZAKAT COLLECTION IN OPTIMIZING THE POTENTIAL OF ZAKAT IN WEST JAVA CASE STUDY OF WEST JAVA BAZNAS
}

\begin{abstract}
Ahmad Syakir ${ }^{1,}$ Lutfi Zulkarnain ${ }^{2}$
${ }^{1}$ SEBI: Email: ahmadsyakir2111@gmail.com

${ }^{2}$ SEBI Lecturer Email : lutfizulkarnain@gmail.com

ABSTRACT. This study aims to analyze the strategic effectiveness of Zakat collection carried out by West Java BAZNAS. In this study the author uses a qualitative approach, with data collection techniques that are descriptive analysis. The data used in this study were obtained from the results of observations at the place of research, direct interviews with related sources, and collection of documentation as data collection techniques in this study. The results and findings of this study indicate that the collection of zakat made has a decrease. Where there are internal factors of West Java BAZNAS that have not been optimal and public awareness in carrying out zakat is still low. This research is expected to be a reference for zakat institutions, academics, and the public about the need for support in collecting zakat.
\end{abstract}

Keywords: Effectiveness of Collection, Zakat, West Java BAZNAS

\section{INTRODUCTION}

Indonesia consists of various ethnic groups, languages, and religions. Based on the family race (race), Indonesia consists of indigenous peoples, namely the Southern Mongoloid / Austronesian and Melanesian, where the tremendous Austronesian people inhabit the more significant part of western Indonesia. More specifically, Javanese are the largest ethnic group, with a population reaching $41.7 \%$ of the entire population of Indonesia. Indonesia's national motto, "Unity in diversity" ("Different but still one"), means the sociocultural diversity that shapes one unit/country (Suryadinata, Arifin, Ananta, 2003). In addition to having a dense population and large area, Indonesia has natural areas that support the second most significant level of biodiversity in the world.

Furthermore, among the diversity that exists, there is one province with a sizeable Muslim population and also has great potential that is the province of West Java. Where West Java is the province with the most population in Indonesia, we can see that from the data released by the Central Statistics Agency or BPS West Java. That the population in West Java has increased every year, this can be seen from table 1, which has been shown below. 
Jurnal Ekonomi dan Perbankan Syariah

Vol. 7. No.2, 0ktober 2019: 58-69, ISSN (cet): 2355-1755 | ISSN (online): 2579-6437

Table 1 Number of Population in West Java in 2011-2016

\begin{tabular}{|c|r|}
\hline \multicolumn{1}{|c|}{ YEAR } & \multicolumn{1}{|c|}{ POPULATION } \\
\hline 2011 & $43,938,796$ \\
\hline 2012 & $44,643,586$ \\
\hline 2013 & $45,340,799$ \\
\hline 2014 & $46,029,668$ \\
\hline 2015 & $46,709,569$ \\
\hline 2016 & $47,379,389$ \\
\hline
\end{tabular}

Sumber: BPS Indonesia

West Java. Furthermore, it can also be utilized in developing resources owned by West Java. In addition to economic potential, West Java is also the largest Muslim population in Indonesia. That is, around $98.3 \%$ of them are residents who adhere to the religion of Islam or Muslims (Statistik, 2014).

So it is very natural that the population of West Java province has a high level of religion. It can be seen from the many pesantren that were born in every region in West Java, but also, it was proven by a large number of delegations sent by West Java at the Musabaqoh Tilawatil Qur'an National Conference. Besides, it can be seen from the number of pilgrimage quota, which has increased from year to year in order to meet the needs of the people of West Java.

According to research conducted by the Islamic Research And Training Institute or IRTI in 2012. Indonesia has three provinces that have high zakat potential. Where the province of West Java is the province with the highest zakat potential, that reached Rp. 17.67 Trillion, and this is the highest. It is then followed by the provinces of East Java and Central Java. Furthermore, if the total number of potential provinces is summed up, then it can be said to constitute $56.20 \%$ of the potential for zakat nationally (Firdaus, Beik, Irawan, \& Juanda, 2012).

However, it is regrettable, that from the potential that exists. Precisely the amount that can be collected can not be following the real potential. Where according to the data collection of zakat in BAZNAS in West Java, namely in 2016, the zakat collected by BAZNAS in the West Java region is Five Hundred Billion. From these data, it can be shown that the tithe awareness of the Muslims of West Java is still low.

Furthermore, based on the results of reports from external audits, where the authors show in Table 2, shows that the income or zakat collected by BAZNAS West Java from year to year, it decreases. Moreover, interestingly again, there was a significant decline in 2015 towards 2016. There was a difference of up to Three billion 
60 | Ahmad Syakir, Lutfi Zulkarnain : Effectiveness of Zakat Collection in Optimizing The Potential of Zakat in West Java Case Study of West Java Baznas

Table 2 Number of Zakat Collections in West Java in 2015-2017

\begin{tabular}{|l|l|}
\hline \multicolumn{1}{|c|}{ Tahun } & \multicolumn{1}{c|}{ Jumlah Penghimpunan Zakat } \\
\hline 2015 & 20.284 .981 .264 \\
\hline 2016 & $16,910,273,708$ \\
\hline 2017 & $15,454,218,650$ \\
\hline
\end{tabular}

Source: West Java Baznas Collection Data Report.

According to the table above, there is a lack of awareness in paying zakat in West Java. Why is that? We will see, where there is a culture of society and the Amil Zakat Institution there is a significant increase in the awareness of zakat only at the moment of Ramadan. However, when in the other months, awareness is not like in the month of Ramadan.

Then the public should be able to comprehend zakat comprehensively. That is viewed from various aspects, in addition to legal issues, also socioeconomic and welfare issues at large. Zakat, infaq, and sadaqah are maliyah worship (in the field of property), which has a significant social role in realizing the welfare of the community so that its position as al worship al-maaliyah alijtimaiyah (worship of wealth that has a social impact). Zakat, which, besides being believed as an obligation, must be seen as a necessity, so that it can become a lifestyle.

Therefore, it needs a strong push to pay zakat to amil zakat. Where there is profit, people do not have to bother sharing it, why? Because the Amil Zakat Institution can distribute optimally and adequately. Even then, the Amil Zakat Institute will provide reports independently and transparently about its accountability. Because it is already a sharia provision that zakat is managed by Amil, not only from the sharia aspect. That the Law or Law also regulates the matter, which is contained in Law No. 23 of 2011.

If we look at Law No. 23 of 2011 concerning zakat management, the Amil Zakat Agency (BAZNAS), the Amil Zakat Institution (LAZ), and the Zakat Collection Unit (UPZ) are institutions that are given the mandate to manage zakat. BAZNAS is a government-formed institution tasked with collecting, distributing, and utilizing zakat. Furthermore, LAZ and UPZ obligations to report the collection and utilization activities of zakat that has been done can be reported to BAZNAS, and there is no obligation to deposit zakat to BAZNAS. 
Jurnal Ekonomi dan Perbankan Syariah

Vol. 7. No.2, 0ktober 2019: 58-69, ISSN (cet): 2355-1755 | ISSN (online): 2579-6437

\section{LITERATURE REVIEW}

\subsection{Zakat Definition}

Zakat is a material obligation and becomes one of the pillars of Islam. It is also calculated as one of the foundations of the Islamic financial and economic system because zakat has represented itself as the primary source of aldlaman al-ijtima' $i$ (social security) financing. Therefore, zakat is also understood as part of the form of jihad in the way of Allah, given its considerable role in achieving economic growth and political excellence (Supeni, 2009). Zakat is one of the obligations that has been recognized by Muslims in an ijma'. Zakat is also a worship service that is so popular that it becomes a necessity in religion (Sabiq, 2006).

According to etymology, zakat means holy (al-thaharah), growing and developing (al-nama'), blessing (al-barakah), and right (thayyib). According to Wahidi in his book Yusuf Qardawi, the basic word Zaka means to grow and grow, so that it can be said, the plant is zaka, which means to grow, while each thing that is added is called zaka means to increase. If one plant grows without defects, then the word zaka here means clean (Qardhawi, 1996).

In other words, the sentence zakat can be interpreted as clean, it can be interpreted as increasing, and it can also be interpreted as being endowed. These meanings are recognized and desired in Islam. Therefore, whoever issues zakat means he cleans himself and purifies his wealth so that it is hoped that his reward will increase and his wealth will be blessed.

\subsection{ZAKAT INSTITUTION}

According to Imam Shafi'i, 'amilun are people who are appointed to collect alms from their owners (Asnaini, 2008: 54.). From this understanding, amil is the people who are in charge of collecting zakat. Then according to Yusuf Qardhawi, 'amilun is "all people who work in the administration of zakat affairs, both collecting, storing, recording, calculating as well as recording and entering and entering alms and distributing it to their mustahik (Qardhawi 2002: 545).

Regarding zakat collection officers, Hasbi chose the opinion of Abu Hanifah and Malik who stated that 'amilun was an officer who was given wages taken from the zakat collection property according to the level of their efforts (Shiddiqi, 2009).

Amil zakat is all parties who act in connection with the collection, storage, safekeeping, recording, and distribution or distribution of zakat assets. (A. Hidayat, 2008: 142) So, amil zakat is people who are involved in or actively participate in zakat implementation activities that start from collecting zakat from muzaki to distributing it to mustahik. 


\subsection{FUNDRAISING}

According to the language, fundraising means raising funds or raising funds. In contrast, according to the term, fundraising is an effort or process of activities in the context of collecting zakat, infaq, shodaqoh as well as other resources from the community, be it individuals, groups, organizations and companies that will be distributed utilized for mustahik. Purwanto, (2014) defines fundraising as a process of influencing the community both individuals as individuals or community representatives and institutions to channel their funds to an organization. The role and function of the collection division are indeed devoted to collecting zakat, infaq funds and endowments from the community. These funds not only come from individuals, but also various companies and institutions.

In the end, the field of the collection can expand the search to foreign countries as well, both the international community, donor agencies, and various companies abroad. In carrying out fundraising activities, the collection section can hold a variety of activities. These various program activities can finally be offered as collaborative programs with other companies and institutions. In the end, fundraising activities are not only in the form of funds. Funding is a process of selling creative ideas that donations can be realized by community change. If people have accepted the idea, then they want to contribute by giving an idea of raising funds, not asking for money (Setyarso, 2008)

\subsection{Fundraising Method}

In carrying out fundraising activities, many methods and techniques can be carried out. The method here is a typical form of activity carried out by an organization in order to collect funds from the community. This method can basically be divided into two types, namely, direct or direct fundraising and indirect funding (Purwanto, 2009).

a. The Direct Fundraising Method

What is meant by this method is a method that uses techniques or ways that directly involve the participation of muzakki. Namely forms of fundraising where the process of interaction and accommodation power to the muzzaki response can be immediately (directly) done. With this method, if there is a desire to make donations in muzakki after getting a promotion from the fundraiser of the institution, then immediately can do it with young people, and all the necessary information to make a donation is available. Examples of these methods are Direct Mail, Direct Advertising, Tele fundraising, and direct presentation.

b. Indirect Fundraising Method

This method is a method that uses techniques or methods that do not involve the direct participation of muzakki. Namely forms of fundraising which is not done by providing direct accommodation to the immediate response of muzakki. This method is, for example carried out with a promotional method that leads to the formation of a strong 
Jurnal Ekonomi dan Perbankan Syariah

Vol. 7. No.2, 0ktober 2019: 50-69, ISSN (cet): 2355-1755 | ISSN (online): 2579-6437

| 63

institutional image without being directed to donation transactions at the time.

\subsection{EFFECTIVENESS}

Effectiveness comes from the word effective, which has several meanings, including 1) there is an effect, 2) brings results, is sufficient (business action), and starts to take effect. From this word also comes effectiveness, which is interpreted by circumstances, influences, impressions, efficacy, and success. Effectiveness is the ability to achieve specific goals in the right way or equipment. (Tresnati, Ratih, Rochaety, 2005)

\section{RESEARCH METHODOLOGY}

The method used in this research is descriptive. Descriptive method is to focus attention on the problems that exist at the time the study was conducted or actual problems and describe the facts about the problem being investigated as it is and accompanied by adequate rationale interpretation (Jamaludin, 2011)

This research intends to understand events or events holistically. So, the research will be conducted using descriptive research methods. This method aims to describe systematically the facts or characteristics of specific populations or specific fields factually and accurately (Jamaludin, 2011). The author uses this method because of actual and factual problems. Because the problem is ongoing right now. While factual, because this research will be based on facts that happened.

\section{RESULTS AND DISCUSSION}

\subsection{EFFECTIVENESS OF ZAKAT FUNDRAISING ON BAZNAS WEST JAVA}

In every institution, there must be a target that must be by planning within the next year, as well as West Java BAZNAS also determines the target of fundraising zakat every year. The determination of the zakat fundraising target was determined in a work meeting attended by the Head of the West Java Regional Organization and several Zakat Management Units under the supervision of the West Java BAZNAS. So that the zakat fundraising plan can be maximized following its potential. Moreover, the collection of Zakat to be effective must meet the following conditions:

\subsubsection{Usefullness}

Usefulness is useful for management in carrying out its other functions. A plan must be flexible, stable, sustainable, and simple. In West Java BAZNAS, it experienced a decline in the zakat fundraising every year. All can be seen from the overall financial statements for the last three years (2015-2017). The zakat fundraising in 2015 amounted to Rp. 20,284,981,264 decreased by $\mathrm{Rp}$ 
64 | Ahmad Syakir, Lutfi Zulkarnain : Effectiveness of Zakat Collection in 0ptimizing The Potential of Zakat in West Java Case Study of West Java Baznas

3,374,707,556. In 2016 the zakat fundraising amounted to Rp16,910,273,708, then for 2017 it declined again by $\mathrm{Rp} 1,456,055,058$ to $\mathrm{Rp} 15,454,218,650$. Therefore, it can be said that the fundraising of zakat in BAZNAS West Java is unstable because each year, the receipt of zakat funds has decreased. This decline has the potential to become a serious threat to BAZNAS West Java.

\subsubsection{Accuracy and Objectivity}

Accuracy and objectivity are all plans that must be evaluated to find out whether it is clear, concise, real, and accurate. BAZNAS West Java, in terms of the presentation of its financial statements, has always been audited independently every year, so the financial statements issued are clear, concise, real, and accurate. It can be seen from the statement letter of the head of BAZNAS West Java regarding Financial Statement Responsibility stating that:

1. Responsible for the preparation and presentation of BAZNAS West Java financial statements.

2. Zakat BAZNAS Management in West Java has been prepared and presented following Law No.23 of 2011, then also Decree of the Minister of Religion of the Republic of Indonesia No. 186 of 2016 concerning the establishment of BAZNAS at the provincial level and strengthened, with the Decree of the Governor of West Java Number 450.12/Kep.919-Yansos/2016 concerning Amendments to the Decree of the Governor of West Java Number 450.12 / Kep.156-Yansos/2015 concerning the Leaders of BAZNAS of West Java for 2015-2020

3. Financial Report BAZNAS West Java has been prepared and presented under Financial Accounting Standards 109:

a) All information in the financial statements of BAZNAS West Java has been published entirely and correctly.

b) The financial statements of BAZNAS West Java do not contain material information or facts that are not true and do not omit material information or facts

4. Responsible for the internal control system in the West Java National Amil Zakat Agency.

5. Voluntary reporting such as publishing the Mazaya magazine every two months and publishing a bi-monthly newsletter. So that every month BAZNAS West Java presents voluntary reports once a month in the form of Mazaya magazines and bulletins.

6. Have a zakat database that is entirely consistent and accurate through developing a sustainable database system.

\subsubsection{Scope}

The scope needs to pay attention to the principles of completeness, cohesiveness, and consistency. In this case, the West Java BAZNAS collects zakat from Civil Servants following the Decree of the Governor of West Java Number 450.12 / Kep.919-Yansos / 2016 concerning Amendments to the Decree of the Governor of West Java Number 450.12 / Kep.156-Yansos / 2015 concerning the Head of the BAZNAS Province West Java Period 2015-2020. BAZNAS has the authority to collect Professional Zakat and Social Charity from 
Jurnal Ekonomi dan Perbankan Syariah

Vol. 7. No.2, 0ktober 2019: 50-69, ISSN (cet): 2355-1755 | ISSN (online): 2579-6437

\section{| 65}

Civil Servants of West Java Province. In the decision, there is a regulation on professional zakat management carried out by BAZNAS West Java.

\subsubsection{Cost-Effectiveness}

In this case, the cost-effectiveness concerns time, effort and emotional flow. In regards to the time and effort that the receipt of funds. Therefore, it can be seen from the data presented by the author. The data to be presented is the Annual Report of BAZNAS West Java 2015 to 2017. Furthermore, it is presented in order to measure the cost-effectiveness of the West Java BAZNAS:

Table 3: Types of Total Distribution and Beneficiaries.

\begin{tabular}{|c|r|r|r|}
\hline $\begin{array}{c}\text { Distribution } \\
\text { Performance }\end{array}$ & $\mathbf{2 0 1 7}$ & $\mathbf{2 0 1 6}$ & $\mathbf{2 0 1 5}$ \\
\hline $\begin{array}{c}\text { Amount of Funds } \\
\text { Distributed (Rp.) }\end{array}$ & $19,807,521,532$ & $4,893,411,096$ & $6,131,107,300$ \\
\hline $\begin{array}{c}\text { Number of Beneficiaries } \\
\text { (people) }\end{array}$ & 41,574 & 18,855 & 16,432 \\
\hline $\begin{array}{c}\text { Average Beneficiaries } \\
\text { (Rp.) }\end{array}$ & 476,440 & 259,529 & \\
\hline
\end{tabular}

Table 4.1 Types of Beneficiaries

\begin{tabular}{|c|r|r|r|}
\hline Types of Beneficiaries & \multicolumn{1}{|c|}{2017} & $\mathbf{2 0 1 6}$ & \multicolumn{1}{c|}{$\mathbf{2 0 1 5}$} \\
\hline Direct Individuals (People) & 2,086 & 552 & $\mathbf{7 , 0 2 2}$ \\
\hline Through Institutions / Groups (People) & 2,125 & 543 & 200 \\
\hline
\end{tabular}

Table 4: Distribution per Program for All Cities / Regencies

\begin{tabular}{|c|r|c|r|r|r|r|}
\hline \multirow{2}{*}{ Program } & \multicolumn{2}{|c|}{2017} & \multicolumn{2}{c|}{$\mathbf{2 0 1 6}$} & \multicolumn{2}{c|}{2015} \\
\cline { 2 - 8 } & $\begin{array}{c}\text { Benef } \\
\text { iciari } \\
\text { es }\end{array}$ & $\mathbf{R p}$ & $\begin{array}{c}\text { Benef } \\
\text { iciarie } \\
\text { S }\end{array}$ & Rp & $\begin{array}{c}\text { Benef } \\
\text { iciari } \\
\text { es }\end{array}$ & Rp \\
\hline Jabar Mandiri & 1,453 & $2,168,610,500$ & 283 & $894,795,000$ & 24 & - \\
\hline Jabar Cerdas & 13,02 \\
1 & $3,417,232,000$ & 1,484 & $574,870,000$ & - & - \\
\hline Jabar Sehat & 3,410 & $2,448,043,700$ & 4,193 & $532,895,700$ & - & - \\
\hline Jabar Taqwa & 6,673 & $5,111,159,232$ & 4,501 & $1,742,652,000$ & 80 & - \\
\hline Jabar Peduli & 17,01 & $6,662,476,100$ & 8,394 & $1,148,198,396$ & 16,32 & - \\
\hline
\end{tabular}


66 | Ahmad Syakir, Lutfi Zulkarnain : Effectiveness of Zakat Collection in Optimizing The

Potential of Zakat in West Java Case Study of West Java Baznas

Table 5: Beneficiaries Per Asnaf All Cities / Regencies

\begin{tabular}{|c|c|c|c|c|c|c|c|}
\hline \multirow[b]{2}{*}{ No } & \multirow[b]{2}{*}{ Asnaf } & \multicolumn{2}{|c|}{2017} & \multicolumn{2}{|c|}{2016} & \multicolumn{2}{|c|}{2015} \\
\hline & & $\begin{array}{l}\text { Benefi- } \\
\text { ciaries }\end{array}$ & $\mathbf{R p}$ & $\begin{array}{c}\text { Benefi- } \\
\text { ciaries }\end{array}$ & $\mathbf{R p}$ & $\begin{array}{l}\text { Benefi- } \\
\text { ciaries }\end{array}$ & $\mathbf{R p}$ \\
\hline 1 & Fakir & 15,921 & $3,373,720,000$ & 6,645 & $914,143,300$ & 2,182 & - \\
\hline 2 & Miskin & 15,722 & $10,794,908,399$ & 2,085 & $1,778,150,698$ & 2,182 & - \\
\hline 3 & Fisabilillah & 9,310 & $5,263,716,333$ & 10,022 & $2,150,321,700$ & 2,526 & - \\
\hline 4 & Gharimin & 47 & $215,668,800$ & 23 & $7,210,000$ & 84 & - \\
\hline 5 & Ibnu Sabil & 553 & $135,058,000$ & 36 & $25,522,000$ & 46 & - \\
\hline 6 & Riqab & 0 & 0 & 0 & 0 & 0 & - \\
\hline 7 & Muallaf & 21 & $24,450,000$ & 44 & $18,063,400$ & 1 & - \\
\hline
\end{tabular}

After describing the data of the West Java BAZNAS Annual Report, there are still a lot of inaccurate and inaccurate data. Therefore, when viewed in terms of cost-effectiveness, the West Java BAZNAS was categorized as not yet effective and optimal. Then we will see based on the next indicator.

\subsubsection{Accuracy of Time}

Timeliness is a plan; changes that occur very quickly will cause the plan to be incorrect or appropriate for various time differences. Judging from the timeliness done, BAZNAS West Java in conducting fundraising of zakat is by the plan because the withdrawal is following the salary time that the employees get.

Every collection activity carried out by the zakat management institution must be encouraged by good distribution programs so that no matter how good the collection program, the output will reach distribution. Likewise, with West Java BAZNAS, the success of collection activities is also driven by distribution activities.

Distribution activities that have been trusted by muzakki and have a significant impact on the welfare of mustahik, so that muzakki will always donate zakat, infaq, and shadaqah to BAZNAS West Java. BAZNAS West Java gets ZIS funds from the community of more than one hundred billion rupiahs is undoubtedly not an easy matter. Despite carrying the label "BAZNAS West Java," the acquisition which every year tends to decline is always accompanied by hard and tireless efforts so that the muzaki distribute zakat, infaq, and sadaqah (ZIS) through BAZNAS West Java.

As an official government body, BAZNAS West Java is specifically tasked with collecting and distributing Zakat, Infaq, and Sadaqah (ZIS) funds in West Java Province. Its existence shows a concern for social problems for its citizens. For this reason, the management of BAZNAS West Java seeks to 
Jurnal Ekonomi dan Perbankan Syariah

Vol. 7. No.2, 0ktober 2019: 58-69, ISSN (cet): 2355-1755 | ISSN (online): 2579-6437

\section{| 67}

reform both at the organizational, human resources, and program levels. All three have a positive correlation with the values or principles of functional organization derived from the ten demands of future organizations. The values in question are independent, professional, transparent and accountable, excellent service, influential organizational culture, durable and robust working network, and reliable and robust institutional image. The expectations of stakeholders (represented by the performance survey respondents) led to the Future of the West Java BAZNAS Institution to become a good organization.

The effectiveness of collecting zakat funds in West Java BAZNAS can be seen from the success of collecting zakat funds according to the target set. The acquisition based on the audit results of the overall Financial Statements of West Java BAZNAS for the last three years (2015-2017) is not stable because every year, the receipt of zakat funds has decreased. Also, the effectiveness of zakat fundraising strategies can also be seen from the increase in zakat funds, infaq, and shadaqah collected as a whole from time to time.

However, it has decreased. So, it can be said that the efforts made by BAZNAS West Java to increase fundraising from year to year have not yet been achieved, which can be proven from the effectiveness of the collection of zakat funds applied so far both from corporate zakat, professional zakat, and donors from other communities. Thus, the strategy of collecting zakat BAZNAS West Java certainly must be accompanied by innovative steps to optimize the potential of Zakat in West Java. Fundraising optimization of zakat from sources can be maximized, and even untouched can be absorbed to the fullest.

\subsection{INDICATOR TABLE OF EFFECTIVENESS OF ZAKAT FUNDRAISING}

After the authors describe the collection strategy, then explain in detail related to the effectiveness indicators of collection conducted by BAZNAS West Java, then the authors make a simple presentation using tables, which will then make conclusions and suggestions

Table 6: Indicator Table of Effectiveness of Zakat Fundraising

\begin{tabular}{|c|c|c|}
\hline No. & Indicator & Achieved \\
\hline 1. & Kegunaan & Yes \\
\hline 2. & Ketepatan dan objektifitas & Yes \\
\hline 3. & Ruang Lingkup & Yes \\
\hline 4. & Efektivitas Biaya & No \\
\hline 5. & Ketepatan waktu & No \\
\hline
\end{tabular}




\section{CONCLUSION}

After conducting the analysis and discussion in the previous chapter, the writer concluded to answer the problem that the writer raised. Among others are: 1. Several factors cause constraints faced by BAZNAS West Java in conducting collection. Among them are: First, the perception that has not been built about the obligation of tithing and the importance of zakat through official institutions to be more effective in empowering the dhu'afa. Second, the still lack of knowledge about the correct way of tithe according to the guidance of the Koran and the hadith of the Prophet, peace be upon him, in general, the Muslim community still understands that zakat is only synonymous with taking alms of fithrah alone in the month of Ramadan. Third, the optimal functioning of laws and regulations governing zakat management among the Government, BAZNAS, and the Amil Zakat Institution (LAZ). Fourth, the trust of Muslims, in general, has not yet been developed in the management of zakat. Fifth, not all employees are willing to deduct automatic zakat from monthly salary, as a form of facilitation for muzakki from employees. Seventh, Limited Competency of human resources in the utilization of zakat, which is more productive and innovative.

2. Effectiveness in collecting Zakat by BAZNAS West Java can be categorized as not optimal. We can see five factors. First, the usefulness or role of West Java BAZNAS in collecting zakat, it can be categorized as optimal. Secondly, the accuracy and objectivity of the role of the West Java Province can be said. It can be categorized as useful. Third, the scope or scope of the area that is collected, this is very effective. Because it is strengthened by the Law and Decree of the Governor of West Java, it can be said to have been effective. Fourth, the cost-effectiveness of West Java BAZNAS is categorized as ineffective, because there are some incomplete reports. Fifth, timeliness or whether the collection and distribution can be appropriately maximized. However, there are always funds that are not optimal, so the timeliness is not compelling. That way, of the five factors that exist and only three, are met. So it can be categorized as BAZNAS West Java not yet effective in optimizing the Zakat potential in West Java. 
Jurnal Ekonomi dan Perbankan Syariah

Vol. 7. No.2, 0ktober 2019: 50-69, ISSN (cet): 2355-1755 | ISSN (online): 2579-6437

| 69

\section{REFERENCES}

Al-Qur'anul Kariim.

Al-Qurthubi. (1993). al-Jami' Li Ahkam al-Qur'an (pp. 112-113). Beirut Lebanon: Daar el-Kutub.

Ayyub, H. (2003). Fikih Ibadah. Jakarta: Pustaka Al-Kautsar.

Firdaus, M., Beik, I. S., Irawan, T., \& Juanda, B. (2012). Economic estimation and determinations of Zakat potential in Indonesia. Islamic Research and Training Institute, WP 1433-07(August), 1-74. https://doi.org/10.1002/mop.23534

Hafidhudin, D. (2002). Zakat Dalam Perekonomian Modern. Jakarta: Gema Insani.

Handoko, H. (2003). Manajemen (pp. 103-105). Yogyakarta: BPPE.

Jamaludin,A.N (2011). Metode Penulisan Skripsi Untuk Mahasiswa. Bandung: CV Pustaka Setia.

Moeleng, L.J (2013). Metodologi Penelitian Kualitatif. Bandung: Remaja Rosda Karya.

Mulyasa, E. (2004). Manajemen Berbasis Sekolah, Strategi, dan Implementasi (p. 82). Bandung: PT Remaja Rosda Karya.

Mursyidi. (2003). Akuntansi Zakat Kontemporer. Bandung: PT. Remaja Rosdakarya.

Nawawi, I. (2013). Manajemen Zakat dan Wakaf. Jakarta: VIV Press.

Purwanto, A (2009). Manajemen Fundraising Bagi Organisasi Pengelola Zakat. Yogyakarta: Teras.

Purwanto, A. (2009). Manajemen Fundraising Bagi Organisasi Pengelola Zakat (pp. 11-17). Yogyakarta: Teras.

Purwanto, A. (2014). Fundraising. Retrieved from http://hidayatmuflih.blogspot.com/2014/03/pengertianfundraising.html

Qardhawi, Y. (1996). Hukum Zakat: Studi komparatif mengenai status dan filsafat zakat berdasarkan Qur'an dan Hadits. Bogor: Pustaka Litera Antarnusa.

Rasjid, S. (2010). Fiqh Islam. Bandung: Sinar Baru Algensindo.

Ridho, M. T. (2007). Zakat Profesi dan Perusahaan. Jakarta: Institut Manajemen Zakat. 